\title{
The Non-Existent May Cycle: Methods, Colonial Texts and Epigraphy
}

\section{Péter Bíró}

\section{(2) OpenEdition}

\section{Journals}

Electronic version

URL: https://journals.openedition.org/jsa/12310

DOI: 10.4000/jsa. 12310

ISSN: 1957-7842

\section{Publisher}

Société des américanistes

\section{Printed version}

Date of publication: 31 December 2012

Number of pages: 33-57

ISSN: 0037-9174

\section{Electronic reference}

Péter Bíró, "The Non-Existent May Cycle: Methods, Colonial Texts and Epigraphy", Journal de la Société des américanistes [Online], 98-2 | 2012, Online since 10 December 2015, connection on 03 September 2022. URL: http://journals.openedition.org/jsa/12310 ; DOI: https://doi.org/10.4000/jsa. 12310 


\title{
THE NON-EXISTENT MAY CYCLE. METHODS, COLONIAL TEXTS AND EPIGRAPHY
}

\author{
Péter BÍRÓ *
}

\begin{abstract}
More than three decades ago, Munro Edmonson suggested that Postclassic Yukatek Maya political organisation was based on a 256-year long may cycle, where each site competed to be the cycle seat. Several authors used this particular model to interpret diverse social and political patterns attested in Mesoamerican civilisations. In this paper, I examine Colonial Yukatek documents and epigraphy in order to look for the existence of such a cycle. Emphasising methodological issues of translations and interpretations of Colonial and pre-Hispanic texts and re-analysing several Chilam Balam passages, I suggest that Edmonson's translation of the relevant sentences are incorrect. Also, I argue that such a word did not exist in Classic period inscriptions. Current ideas based on such a model should therefore be re-examined in light of these findings and other evidence should be used in order to prove their plausibility. [Key words: Maya, may cycle, epigraphy, Chilam Balam.]
\end{abstract}

La non-existence du cycle may: méthode, textes coloniaux et épigraphie. Il y a plus de trois décennies, Munro Edmonson a suggéré que l'organisation politique yucatèque du Postclassique était fondée sur une période de 256 ans (le may), où les sites entraient en compétition pour être le siège du cycle. Plusieurs auteurs ont fait valoir que cette organisation existait déjà au Classique. Dans cet article, on examine les données de l'épigraphie et les documents coloniaux yucatèques afin d'y trouver des éléments sur l'existence d'un tel cycle. Après l'examen de plusieurs passages des Chilam Balam, il est apparu que la traduction d'Edmonson n'est pas correcte et qu'il n'existe, en réalité, aucune preuve de l'existence de may, ni au Postclassique, ni au Classique. [Mots-clés: Maya, cycle de may, épigraphie, Chilam Balam.]

El ciclo may que no existe: método, textos coloniales y epigrafía. Más de tres décadas atrás, Munro Edmonson sugirió que durante la época Posclásica la organización política maya-yucateca funcionaba en base a un periodo de 256-años (el may) en el que los lugares competían para ser la sede del ciclo. Algunos autores aplicaron este modelo para explicar varios patrones sociales y politicos en existencia en civilizaciones meso-

* Abteilung für Altamerikanistik, Institut für Griechische, Lateinische Philologie, Romanistik und Altamerikanistik, Rheinische Friedrich-Wilhelms Universität, Bonn [bpetr30@gmail.com].

Journal de la Société des Américanistes, 2012, 98-2, pp. 33-57. (C) Société des Américanistes. 
americanas. En este trabajo se revisan documentos coloniales yucatecos y textos epigráficos con el fin de buscar la existencia de dicho ciclo. Con especial énfasis en los asuntos metodológicos de traducción e interpretación de los textos coloniales y prehispánicos se investigan varias partes de los Chilam Balam y se llega a la conclusión de que la traducción de Edmonson es incorrecta. Además, después de analizar los textos del periodo Clásico fuerza es de concluir que tampoco hay evidencia del may en aquella época. Por tanto, ideas contemporáneas que usan el modelo del may deben ser re-examinadas. [Palabras claves: Maya, ciclo may, epigrafía, Chilam Balam.]

In 1979 Munro Edmonson presented an influential paper at the Mesa Redonda de Palenque where he discussed whether certain social and political phenomena were in existence among the Postclassic and Classic Maya periods. In this article for the first time he mentioned his ideas about the existence of a may cycle which referred to a period of thirteen katuns or 256 years:

Did the Classic Maya recognize seats of the cycle (may)? The Books explicitly say they did. In the Postclassic and later, the cycle seat ( $m a y ~ c u$ ) was the primate city of a region. It was not a capital in any normal sense, but rather a holy city, recognized by the title Born of Heaven (ziyan can, can sih), and notable for its sacred ceiba tree (yax che), its sacred grove (tzucub te), its sacred well (ch'en), and its plaza, which was the crossroads ( hol can be) and navel of the world. In the Postclassic the seat of the cycle for the Itza, the « Well of the Cycle » or Mayapan from 1243 to 1752, was not even inhabited after 1452 , but it continued to serve as a symbol of the religious authority of the may for another three hundred years. Perhaps the major centers of the Classic Maya were also seats of the cycle. (See Appendix.) Like the katun, the may is uniquely Yucatecan in the ethnohistorical record, and it is known to be prominent among the Classic Maya, being usually identified as the " count » (kahlay) or " fold » (uutz') of the katuns. What is at issue here is how the Classic Maya used it. It does not seem to me farfetched to suggest that the apogee of the Classic cities may have corresponded to counts of the may, as the following closely related question suggests. It would not be necessary to posit that all Classic cities operated on the same synchronized cycle. The Postclassic Xiu and Itza, for example, disagreed on when to begin and end the may. (Edmonson 1979, p. 11)

Later, Edmonson presented a more detailed model in his two publications about the Tizimin and Chumayel manuscripts, conventionally called Chilam Balam in modern scholarly literatures (Edmonson 1982, p. xvi; 1986, pp. 4-5). The particular ideas surrounding the may were later taken up by various scholars, most recently by Rice (2004, 2007, 2008), who, in several books and articles, applied such a model as the main organisational principle of Maya politics during the Classic and Preclassic Periods.

In 2004, Prudence Rice published Maya political science: time, astronomy, and the cosmos in which she detailed her view about the underlying principles of Classic Maya political organisation. Using a direct historical approach, she 
suggested that Classic period political organisation worked similar to its later successor, 16th century Yukatek Maya political organisation:

I propose here that Classic Maya political organization is best understood by means of the direct-historical approach, that is, by retrodicting elements of Postclassic and early Colonial period organization back into the Classic period. I hypothesize that Classic (and also Preclassic) Maya geopolitico-religious organization was structured by Maya calendrical science, particularly the intervals of approximately twenty years ( $k^{\prime}$ atun) and 256 years, or thirteen $k^{\prime}$ atuns (may « cycle »). By analogy with Postclassic and early Colonial period Yucatan, Mexico, Classic sites hosting the may for 256-years periods were capitals of territories in which k'atun seats rotated among other dependent sites. Portions of the elaborate ceremonies carried out when the Postclassic calendrical cycles ended and began anew can be recognized in the images and inscriptions on Classicperiod carved monuments at Tikal, Guatemala, and other southern lowland sites. May and k'atun seats can be identified archaeologically by the erection of stelae commemorating $k^{\prime}$ atun endings and shared distinctive architectural complexes associated with the celebration of these calendrical observations. In addition, the may hypothesis provides insights into the nature of rulership, ballgame ritual, and warfare among the Classic lowland Maya. (Rice 2004, p. xv)

Rice (ibid., p. 77) not only used the proposals of Edmonson, but also the arguments of Justeson and Campbell (1997, pp. 49-52) who suggested that the original reading of the k'atun glyph was * may tun based on early ma phonetic complementation to T528 which they read as TUN. They did not rule out the existence of such word in Classic Ch'olan ${ }^{1}$, and related it to proto-Mije-Sokean * may " to count, divine, adore » and proposed that this was a widely diffused loanword in Mesoamerican languages. Although Justeson and Campbell (ibid., p. 52) explicitly rejected Edmonson's interpretation of the may in Colonial Yukatek ${ }^{2}$ sources as referring to a 256 year period (according to them its basic meaning was « 20 of years »), however they accepted Edmonson's general translation as « cycle ».

Nevertheless, neither Edmonson nor Rice detailed their specific arguments for the existence of such a term in the Colonial manuscripts or dictionaries, which is a necessary first step in any investigation that is based on the use of texts. In the following I would like to re-examine the translations of the relevant passages in various Chilam Balam manuscripts by Edmonson and also investigate Classic period inscriptions in view of may terminology. After a morphemic analysis of the texts, I suggest that Edmonson's translation is erroneous and cannot be used to suggest the existence of a may model for the Postclassic Maya. This leads me to propose that models based on Edmonson's work should be re-evaluated. Also, I argue for a greater methodological caution in the use of existing translations of the Chilam Balam manuscripts and the necessity to undertake morphemic translations which are based on the application of grammar and not on a lexemic 
translation, or better said a "return back to philology » in case of Native American texts coming from the Pre-Columbian and Colonial areas.

In this paper I first present some methodological suggestions in translating Colonial Mayan and Mesoamerican texts. Then I follow with a search for the may « cycle » in Classic period inscriptions. Last, I proceed to investigate the proposed readings of may by Edmonson in the Colonial Yukatek sources.

\section{METHOD}

Dealing with Native American texts was never easy as they did not form part of our traditions. This is coupled with the relatively few available grammars and dictionaries during the Colonial period and sometimes with the actual extinction of the languages in which texts were written. In the case of Pre-Columbian traditions, an even bigger obstacle is the linguistic distance from 16th century descendants whose languages were first recorded by Europeans and the different and only partially deciphered writing systems which served as vehicles to record them.

Priests and friars made serious efforts to compile grammars and dictionaries in order to understand and thus convert with more ease the newly discovered subjects of the New Worlds. It is still to be written how the development of Biblical criticism and implicit philology influenced this work. What is important is the use of native language sources which stopped to be written somewhere in the 19th century when the Colonial Regime collapsed and the necessity of such written material lost its importance. It was at the same time when scholars from all over the world started collecting those very materials. Such native language sources were always deemed to be invaluable and their translations by pioneering scholars such as Brasseur de Bourboug, Brinton, Morley and later Roys, in the case of the Mayas, influenced scholarship up to the present (Restall 1998, 2003).

Not to denigrate the magnificent achievement of these early works, some of them still used today, I would argue they lacked a methodological sophistication because of the dearth of native materials and also because of their authors' inexperience to deal with text from a philological viewpoint. Philology, as one of its current and most brilliant exponents puts it, is « the discipline of making sense of texts » (Pollock 2009, p. 934). While it is not linguistics, it needs to use the achievement of this discipline especially in its dealing with texts which first of all require translations to make sense of them. Such an attitude was taken up again by many scholars who investigated indigenous sources from Mesoamerica and called their approach "New Philology », where emphasis is on the detailed morphemic and grammatical translation of texts with commentaries as the first step of making sense of them (Restall 2003).

New Philology as such, is not trying to restore texts from different editions into their supposed original format - as is/was one of the main tasks of philology 
in the past (stemmatic method) - but approaches native language sources with a better understanding of the languages, especially their grammar, which leads, I would argue, to better translations of these texts.

Edmonson's translation specifically builds on a method which William Hanks in his review article called « an appeal to semantic organization » that was a previously frequent methodological approach in dealing with native texts (Hanks 1988, p. 333). This method consists in the collection of basic word entries; however, it does not detail the syntax or phrase structure of the specific text in the object language (Edmonson 1986, pp. 3-4; Hanks 1988, pp. 334-336). The approach of Edmonson is generally lexical which leads to several errors in the morpheme identification and thus the segmentation of the texts. This results into grammatically implausible translation which is frequently explained by the assumed esoteric nature of these manuscripts (Hanks ibid., p. 333).

To remedy such errors of segmentation and doubtful translation, Hanks (ibid., p. 361) suggests a methodological approach which translates texts according to the grammatical conventions of Mayan language. This is a truism in Old World philology, but only a very recent phenomenon in studies dealing with native textual sources from the Americas, be they from the Colonial or the Pre-Columbian period (Restall 2003).

At present such grammatical translations are missing in cases of most Mayan texts, although a recent and excellent work by Maxwell and Hill (2006) of 16th and 17th centuries Kaqchikel documents, a translation of the Chilam Balam of Kaua by Bricker and Miram (2002), the publications of Knowlton (2010), Breton (2004) and the work of van Akkeren (2000) with Colonial Highland Mayan documents indicate that New Philology is also influencing Maya textual scholarship.

While New Philology in the Americas was not intending to develop critically edited texts of the various native American sources, as in most cases such versions are simply non-existent, recent scholarship about Chilam Balam manuscripts by Gunsenheimer $(2002,2003,2006)$ used fruitfully the stemmatic method (best text edition) by taking into account parallel or nearly parallel passages in different versions.

Because such parallel passages are available and are amply documented and presented by the transcriptions and concordances made by Miram and Miram (1988a, 1988b) and Bricker (1990a, 1990b), it is easier to compare text segments than it was before. Therefore, translations of passages and eventually whole texts should be based ideally on a morphemic segmentation of the written text which implies the correct or best possible identification of the different linguistic components. Because in many cases, phonological phenomena are under-represented in Colonial documents, and especially in the Chilam Balam manuscripts, the morphemic segmentation can help to disambiguate homophonous and/or homographic lexemes. 
Certainly one major problem of such a grammatical approach of Colonial Yukatek documents is the lack of available grammars of the language. Apart from the works of McQuown (1967) and that of Smailus (1989), Colonial Yukatek grammars remain that of Buonaventura (1996 [1684]) and Beltrán de Santa Rosa Maria (2001 [1746]). In my translation I used the work of Smailus, being the most comprehensive one. However, there is more work to be done with our understanding of Colonial Yukatek.

Unravelling the various genres represented in these documents also contributes to the translation process. Edmonson's significant contribution in this field points out the importance of couplet in organising Yucatec Mayan discourse. However, by extending the couplet to every text segment in the Chilam Balam, he sometimes misidentified other literary/poetic devices which are now amply attested in Classic Maya and Colonial Mayan literatures (Tedlock 1983, 2010; Hull 2003; Breton 2004; Gunsenheimer, Okhosi and Chuchiak 2009). Taking into account such principles both in Classic period and Colonial literatures also contributes to better translation of these documents (Hanks 1986, 1987, 1989, 2010).

\section{MAY IN CLASSIC PERIOD INSCRIPTIONS}

In their article, Justeson and Campbell (1997, pp. 49-52) detail their arguments for reading the early form of a glyph which was certainly referred to a 20 -year period (and later called k'atun in Classic Yukatek) as *may tun, based on a phonetic reading of ma-TUN, which they argued was the early reading of a Classic period ka-TUN.

Although this article was published in 1997, it is important to know that the paper was first presented in 1989, reflecting the then current knowledge of epigraphers. Among the many gains of recent scholarship about Maya hieroglyphic writing in the last twenty years, is the discovery of digraphs and even trigraphs, or the combination of two or three signs to form an altogether new sign with a new reading. While Justeson and Campbell identified the top sign of the k'atun glyph as T25-T528-T25 and read it as ka-TUN-ka arguing for the optionality of the second ka syllabogram, it is clear that this sign combination stands for the logogram WINAK/WINIK with the meaning " 20 », which is shown by occasional wi- and -ki phonetic complements (Figure 1$)^{3}$. It forms with the T548 HAB' a composite glyph which reads as WINAK/WINIKHAB' or " twenty haab" « (twenty times 360 days). Indeed, it never occurs outside of this specific glyph, which indicates a unique composite grapheme.

May is therefore not participating in the reading of this particular glyph, however it does occur in Classic period inscriptions (Stuart 2005, p. 154, notes 45 and 46). First, it is the reading of T795 (MAY-first suggested by Linda Schele in 1979 in a personal communication to David Stuart as cited in Stuart ibid., 


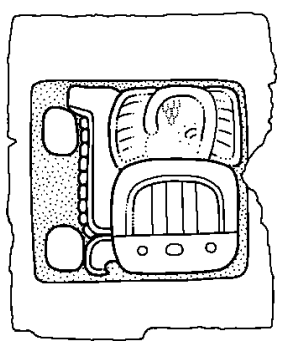

FIG. 1 - 2-wi-WINIKHAB'/cha' winikhaab' (MS 14 Edzna; drawing by Guido Krempel).

note 45) which can be transcribed as may (Figure 2). While it represents deer hoof, the grapheme stands in two different contexts: either to refer to sacrifice, gift or to tobacco (examples are coming from Stuart ibid.):
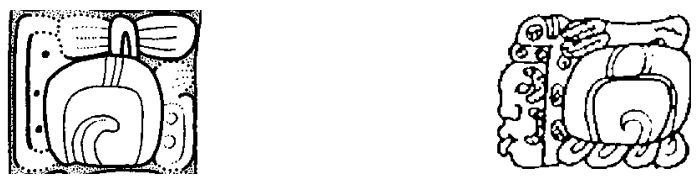

FIG. 2 - u-ma-yi-ji/u mayij (Tortuguero Wooden Box Glyph 4; drawing by Sven Gronemeyer) and u-MAY-yi-ji/u mayij (Palenque Palace Tablet G14; drawing by Merle Green Robertson).

$\begin{array}{lll}\text { u-ma-ya } & \text { u may } & \text { his tobacco (snuff) } \\ \text { MAY-yi-ji/hi } & & \\ \text { ma-yi-ji } & \text { mayij/ih } & \text { gift } \\ \text { MAY-ji-li } & \text { may }[i] j i l & \text { sacrificial }\end{array}$

As Stuart (ibid.) argued persuasively mayij «was an ancient term for bloodletting, including the passing of cords through the tongue ». Nevertheless, it does not have anything to do with periods of twenty years, and less so with a period of thirteen k'atuns. Arguments for the existence of a word may with the meaning of «cycle » are neither attested in Classic Maya inscriptions, nor with the meaning of a " period of thirteen k'atuns ».

Another context of this word is found in the inscriptions of Chichen Itza, regionally the closest to the writers of the Postclassic sources and arguably a place with Yukatek vernacular speakers during the Classic period (García Campillo 2000; Lacadena and Wichmann 2004). As was first pointed out by Voss and Kremer (2000, pp. 162-164), on Lintel 4 of the Temple of the Four Lintels, in a fire ceremony (ta-pa-li-ki K'AK') involving a TOK'-PAKAL-la (a difrasismo which refers to armies and also more concretely to ceremonial objects such as " flint-shield ») the named celebrants have all certain specific relations to this particular object (Figure 3): 
to'k' pakal

u kanan may k'ahk' u pakal k'awiil ? ti chaan pas

u mayan k'in? yajaw k'ahk' b'aah te' pas

yitaaj ak'e to'k'? ? ajaw yajaw k'ahk'

u tajal k'uhul wahujaw

u tajal

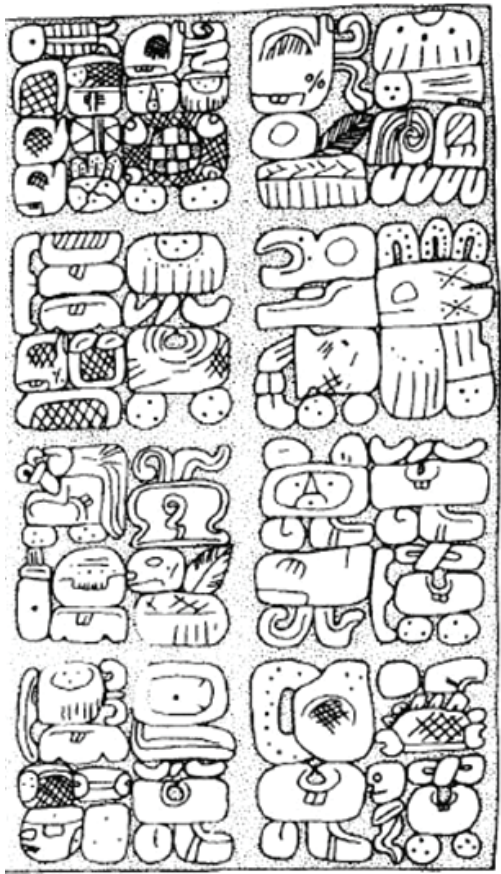

FIG. 3 - Lintel 4 of Temple of the Four Lintels E1-H4 (Chichen Itza; drawing by Ruth Krochock).

In another fragmented text from the Caracol (Figure 4), a bih tuun is again the kanan may of a god called Yax Pech Noj Kan (bi-TUN-ni u-ka-na-na-ma-ya YAX-pe-che-NOJ KAN).

From the syntax, it is possible to know that the to' $k^{\prime}$ pakal (and the bih tuun) is the kanan may, the mayan and the tajal $^{4}$ of the various persons. Each term has its own problem of translation, but from the context the meaning of «cycle » or « a period of $13 \mathrm{k}$ 'atuns » can be ruled out. Indeed all Colonial dictionaries give appropriate glosses for the terms and they are also analysable from Colonial grammar (Cordemex 293): 

kanan guardar casa, ganado, cosas y personas asi guardar y tener cargo de algo guardar y cuidar
kanan/ cosa que uno tiene guardada kanana'n

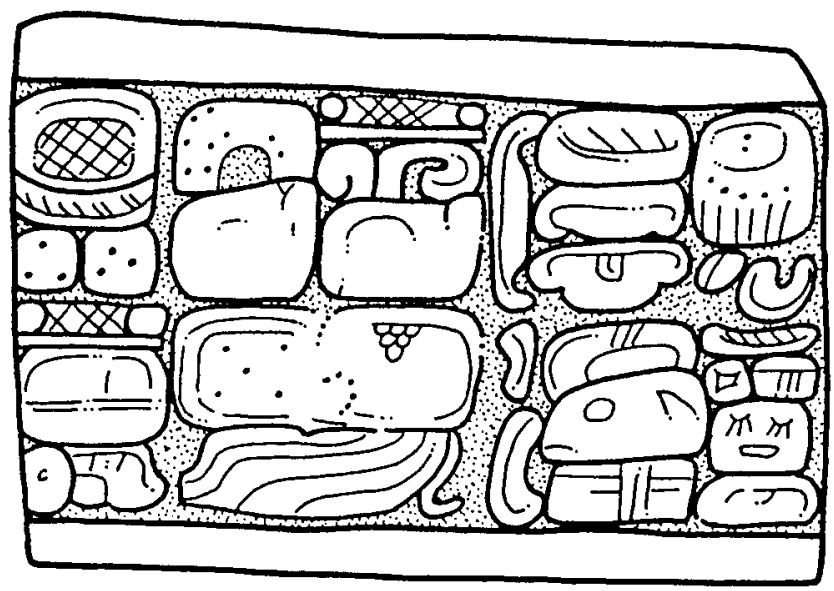

Fig. 4 - Caracol Hieroglyphic Band Fragment 12 (drawing by Erik Boot).

The same verb and its derivation are frequently found in Classic period inscriptions with captives and children. Usually prefixed with an ergative pronoun and postfixed with the syllabogram -nu with the reading of cha'n and loosely translated as « the guardian of... » ${ }^{5}$. The form in Chichen Itza is Yukatek and it shows a verbal root kan-with a reconstructed -an participle suffix resulting in the past participle kanan which means "guarded (thing or person) ». May in this context has to be a noun, however in the following line, it is derived with the same -an participle suffix indicating that it also functioned as a verb. From these contexts (morphosyntactic) among the attested meanings of may, only " gift » does seem to be appropriate. In Colonial dictionaries there are the following entries for may and its derivations all referring to " gift, donation » or « adoration »:

$\begin{array}{lll}\text { Ch'olti' } & \text { maii } & \begin{array}{l}\text { Dar de gracia, dadiva, don } \\ \text { (Robertson, Law and Haertel 2010) } \\ \text { Kaqchikel }\end{array} \\ & \begin{array}{l}\text { maih } \\ \text { maiham } \\ \text { maihaxel }\end{array} & \begin{array}{l}\text { donada cosa, famoso } \\ \text { adorable dios, o digno de ser } \\ \text { adorado, amable cosa (Smailus } \\ 1989, \text { p. 526) }\end{array} \\ & & \text { gift }\end{array}$




$\begin{array}{lll} & \text { ah mayih } & \text { doer of goods } \\ \text { mayibal } & \text { miracle (Edmonson 1965, p. 71) } \\ \text { Pokom } & \begin{array}{l}\text { ah mai } \\ \text { mayiij }\end{array} & \text { ofrendor (Miles 1957, p. 750) } \\ & \text { ofrenda (ALMG 2001, p. 55) }\end{array}$

From these entries, it is possible to reconstruct a verb *may-with the meaning of « to gift, to offer, to sacrifice » just as it was done in the case of the Proto-MijeSokean * may « to count, divine, adore " which was widely borrowed into Mesoamerican languages (Justeson and Campbell 1997, p. 51).

Therefore, the meanings of $u$ kanan may and $u$ mayan can be ascertained to be « it is his guarded (in the sense of protected, cherished) gift » and « it is his gift (given thing) ", while in other contexts, a general sense of gift (as sacrifice) is appropriate. Although the original Proto-Mije-Sokean may had among its meanings " to count », this is only attested in Pokomchi, Kekchi, Kiche and Kakchikel always referring to « 20 (years) » and ultimately a count of « 8000 days » (ibid., pp. 50-51).

As a summary of the above arguments, the word may and mayij are attested in Classic period inscriptions referring to gift, sacrifice and to tobacco (in the rare expression of $u$ yotoot $u$ may). On the contrary, there is no context where a meaning of « 20 (years) », or « period of 13 times 20 k'atuns » is ever present.

\section{Colonial (CON)texts}

Colonial texts come from various regions where Mayan languages were or are spoken. Most of the texts, however, originate from Yukatek speakers, and languages from the Guatemalan Highland region such as Kiche and Kakchiquel. Dictionaries are Colonial texts whose orthography and the information in them are sometimes faulty from a perspective of modern scholarship. It is therefore important to examine what the dictionaries preserve about may and its derivations. As I have just presented previously, such meanings can be grouped into four different semantic fields: « tobacco (or any dust, especially which comes after burning or fire) », " offering », « a period of certain years and days (all the time 20, and only attested in Highland Maya languages) » and finally « deer (the hoof) ». In Lowland Maya languages, the " period of certain years and days » semantic field is not attested, while the other three can be ascertained to have existed in Classic Ch'olan and Classic Yukatek, while there is no attestation of the " offering » semantic field in Colonial Yukatek (at least not in the dictionaries).

Nevertheless, Edmonson $(1982,1986)$ in his translations of the Chilam Balam of Tizimin and Mani not only identified various occurrences of the word may, but also translated this term using two semantic fields out of four, that of « deer » 
and of « period of certain years and days », changing the last semantic field into the explicit reference to a " period of 13 times 20 k'atuns ».

To challenge Edmonson's interpretation and translation, I examine each context where he suggested a translation of « cycle » for may in Colonial Yukatek documents. I propose that he not only mistranslated these passages, but also that the intended word was not may but an under-spelling for maya.

Edmonson (1986, p. 4) lists 6 lines from the Chilam Balam of Chumayel (5315) and the Tizimin $(2121,2914,2942,4879,5067)$ where he translates may as " cycle ». As a tendency in his translations, he did not compare manuscripts to have multiple cases and to correct misspellings, under spellings, or sheer errors in grammar ${ }^{6}$. Therefore, in the following I apply a philological approach to these textual excerpts, that is, I present parallel passages from other Chilam Balam manuscripts, and also use a " grammatical » translation (Hanks 1988; Bricker and Miram 2002) instead of the word for word translations applied by so many previous translators. I present in each case morpheme segmentation and identification. For morpheme segmentation I used the transcriptions of Bricker (1990a, 1990b) with modification if it was necessary.

In case of the original orthography, for the Chumayel I had the possibility to check the facsimile edition of Gordon (1913), in the cases of the Chumayel and Tizimin I had access to the transcriptions of Bricker (1990a, 1990b), while in all cases I had access to modern transcriptions by Miram and Miram (1988a, 1988b). I present first the transcription and translation given by Edmonson, and then I proceed with parallel passages. The review of Hanks (1988) about the translation of Edmonson was also very helpful. First I list the Tizimin examples with parallel texts, and then the others if they are not found in the Tizimin manuscript.

\section{Line 2121, original page 6 , folio $3 v^{7}$}

\section{Transcriptions}

ti emom u cuch uitz y okol may cu i uai uchom mayapan t u may ceeh t u xau cutz (T-Ed) ti emom u cuch uitz yokol may cuy uai uchom mayapan tu may ceeh tu xau cutz (T-Mi) tiem-omu-cuchuitz y-ok-olmaycuyuaiuch-ommayapant-u-mayceeht-u-xaucutz ( $T$-Br) eman u cuch uitz yokol may suy uay uchan mayapan tu may ceeh tu xau cutz ( $P$-Mi)

\section{Morpheme Analysis}

ti em-om u-cuch uitz y-ok-ol may cuy uay uch-om mayapan t-u-may ceeh $t$-u-xau cutz

PRE $^{8}$-descend-PAR.EXP 3sERG-burden mountain 3sERG-OVER may cuy ADV happen-PAR.EXP mayapan PRE-3sERG-hoof deer PRE-3sERG-claw turkey

\section{Translations}

« Then will descend the burden of the mountain over may cu, will happen here in Mayapan, 
with/by its [of the burden of the mountain] deer hoof, with/by its [of the burden of the mountain] turkey claw ». (author)

«...which lowered the burden of the mountain over the cycle seat that occurred at Mayapan in the cycle of Ceh in the claw of the Curassow... ». (Edmonson 1982, p. 88) «Entonces será cuando baje la carga a las montañas y a Maycuy, Tecolote-venado. Acontecerá aquí en Mayapan, Estandarte-Venado, aquíen May Ceh, Pezuña del Venado, en Xau Cutz, Guarra-del-guajolote-silvestre ». (Barrera and Rendón 1984, p. 109)

From the parallel lines and translations it can be seen that that there are some major omissions in both. For Edmonson the ti emom is rendered in past and also as a subordinate close of the preceding clause. He consistently translates may as seat in both its occurrences in the excerpt, while Barrera and Rendón translate them as deer and as part of toponyms, however they do not translate the third person singular ergative pronoun in the construction tu may ceeh tu xau cutz.

I present here an alternative translation which takes into account the actual grammar and it is not a word for word translation, and it does not intend to deal with the much more difficult interpretation of the phrase.

«Then will descend the burden of the mountain over may $c u$, will happen here in Mayapan, with/by its [of the burden of the mountain] deer hoof, with/by its [of the burden of the mountain] turkey claw $»$.

In my translation I gave a literal rendering and taking into account discourse without translating may cu. Edmonson's translation of may ceeh as « in the cycle of Ceeh " is forced because of his preconceived ideas of may as cycle. From the context it is possible to ascertain that this is a syntactic parallelism with an opposite semantic pairing between may (hoof) and xau (claw), just as between ceeh (deer) and cutz (turkey; e-mail by Antje Gunsenheimer, 4/08/2010). Barrera and Rendón's translation of the same compounds as toponyms is again flawed because they did not translate the ergative pronouns. Syntactic parallelism is also found in the case of may cu and mayapan opening the possibility that the first is a toponym, just as was translated by Barrera and Rendón. However, such toponym does not exist in any records of the Yucatan Peninsula, which makes this interpretation at first sight dubious, or at least unprovable.

\section{Line 2914 , original page 13 , folio $7 \mathrm{r}$}

\section{Transcriptions}

ha li li uchan T u tz'oc u cuch katun ti to uil y okol mayapan ti uchom may cu (T-Ed) halili uchan tu dzoc u cuch katun ti to uil yokol mayapan ti uchom may cu (T-Mi) hal-ili uch-an t-u-dzoc u-cuch katun ti to u-il y-ok-ol mayapan ti uch-om may cu (T-Br) hali-li uchan tu dzoc u cuch katun ti to yocol mayapan ti uchan may cu (P-Mi) 


\section{Morpheme Analysis}

halili uch-an t-u-dzoc u-cuch katun ti to uil y-okol mayapan ti uch-om may cu

ADV happen-PAR.COMP PRE-3sERG-end 3sERG-burden katun PRE ADV SUBJ 3sERG-over mayapan PRE happen-PAR.EXP may cu

\section{Translations}

« [This] only will happen at the end of the burden of the katun, then it will be there, over Mayapan, then it will happen in may cu ». (author)

" Truly then it is done. The burden of the katun is finished. Which is one moon over Mayapan, the cycle seat... ». (Edmonson 1982, p. 110)

«...pero esto sólo occurirá al final de la carga del katun...Entonces llorará Mayapan, Estandarte Venado, Maycú, Tecolote-Venado ». (Barrera and Rendón 1984, p. 120)

In this passage, the problems of translations abound in both renderings. Although Barrera and Rendón checked the Tizimin and Perez manuscripts, they did not make here a composite text as they left out the following line which appears in the Perez Codex:

halili uchan tu dzoc u cuch katun tu yaxcheil tu sacteil cab

This segment indicates that ti to uillti to yocol mayapan ti uchom may $\mathrm{cu}$ is parallel to tu yaxcheil tu sucteil cab/tu yaxcheil tu tzucteil cab. Edmonson, on the other hand, interpreted the subjunctive enclitic -uil as the noun « moon » (as he done it elsewhere, see the correction in Hanks 1988, pp. 344-348). Also, the relational noun yokol « over, on, upon » was interpreted by Barrera and Rendón as the verb « to cry » $(y-o c-o l)$, however it is clear from parallel passages that this is not the case here. My translation, therefore, is the following:

« [This] only will happen at the end of the burden of the katun, then it will be there, over Mayapan, then will happen in may $c u »$.

The semantic position of may $c u$ in this sentence is again toponymic (just as was suggested by Barrera and Rendón in every case).

\section{Line 2942, original page 13 , folio $7 r$}

\section{Transcriptions}

On cen ah kauil ch'el y etel na puc tun y etel ah xupan nauat $u$ y ah kin noh hal ach uinic hun uitzil chac tutul xiu ti uxmal t u lumil mayapan may cu (T-Ed)

Cen ah-kau-il ch'-el y-et-el na-puc tun y-et-el ah-xupan nauat uy-ah-kin noh halach uinic hun uitz-il chac tut-ul xiu ti uxmal t-u-lum-il mayapan may cu $(\mathrm{T}-\mathrm{Br})$ 
Cen ah kauil ch'el yetel na puc tun yetel ah xupan nauat u yah kin noh halach uinic hun uitzil chac tutul xiu ti uxmal tu lumil mayapan mai cu (T-Mi)

Ten ah kauil yetel ah napuctun ah xupan nauat u yah kin halach uinic ah hun uitzil chac tutul xiu tu billail uxmal tu luumil tzucubte tu cuchcabal mayapan may cu (P-Mi)

\section{Morpheme Analysis}

c-en ah kauil ch'el y-etel na puc tun y-etel ah xupan nauat uy-ah-kin noh halach uinic uitzil chac tutul xiu ti uxmal t-u-lum-il mayapan may cu

ATR.PRO ah kauil ch'el 3sERG-with na puc tun 3sERG-with ah xupan nauat 3sERGpriest big true man hun uitzil chac tutul xiu PRE uxmal PRE-3sERG-landPOSS.PART mayapan may cu

\section{Translations}

«I, Ah Kauil Ch'el and Na Puc Tun and Ah Xupan Nauat, the priests of the great ruler, Hun Uitzil Chac Tutul Xiu, in/of Uxmal, at/from the land of Mayapan may cu ». (author)

«Then I, Kauil Ch'el and Puc Tun and Xopan Nahuatl, the sun priests of the great governor, Hun Uitzil, the rain priest of the Tutul Xiu of Uxmal, in the lands of Mayapan, the cycle seat... ». (Edmonson 1982, pp. 110-111)

Edmonson makes an error in his segmentation of the text, and therefore instead of cen he begins his transcription with on cen which is a non existent combination in Yukatek language. My translation is the following:

« I, Ah Kauil Ch'el and Na Puc Tun and Ah Xupan Nauat, the priests of the great ruler,

Hun Uitzil Chac Tutul Xiu, in/of Uxmal, at/from the land of Mayapan may cu ».

From the above translation, it is again possible to interpret may $\mathrm{cu}$ as a toponym, here as directly following the name of Mayapan. Also, the sequence of the two is reversed and may $c u$ follows Mayapan. They can not only be separated but also put in reverse order which likens them syntactically more to separate entities than an attributive construction.

\section{Lines 4879 and 5067, original page 38, folio 19v}

The two lines are treated here together as they have very similar syntactic and semantic structures. They are parallel passages from a list of katun seatings coming from the same folio of both the Tizimin and the Perez manuscripts.

\section{Transcriptions}

Lai u than y an ychil u cuch y etel $u$ bel $y$ an ychil u cuch hab i lae saciapan u hetz' katun ti cabil ahau sacl ac tun amay cu Mayapan (T-Ed) 
Lai u-than yan ich-il u-cuch la-e y-et-el u-bel yan ich-il u-cuch hab-i lo-e saciapan u hedz katun ti cab-il ahau saclactun amay cu Mayapan ( $\mathrm{T}-\mathrm{Br}$ )

Lai u t'an yan ichil u cuch lae yetel $u$ bel yan ichil u cuch habil lae saciapan $u$ hedz katun ti cabil ahau Saclactun amay cu Mayapan ( $T-M i)$

lay u t'an yan ichil u cuch lae yetel tulacal u bel bin t'anic u t'an saciyapan u hedz katun cabil ahau saclactun may cu mayapan ( $P$-Mi)

\section{Morpheme Analysis}

Lai u-than yan ichil $u$-cuch la-e y-etel $u$-bel yan ichil u-cuch hab-i lo-e saciapan $u$-hedz katun ti ca-bil ahau saclactun amay cu Mayapan

DEM 3sERG-word exist PRE 3sERG-burden DEI-PRO.FOC 3sERG-with 3sERGroad exist PRE 3sERG-burden year-DEI DEI-PRO.FOC saciapan 3sERG-seat katun PRE two ahau saclactun amay cu mayapan

\section{Translations}

« This is its word [which] is in its burden here, and this is its road [which] is in the burden of this year here, [in] Saci(apan) is its katun seat, in 2 Ahau [Katun] [and in/of] Saclactun amay cu Mayapan ». (author)

"This is the word that is in its burden and the road that is the burden of the year. Valladolid is the seat of the katun which is 2 Ahau. Valladolid is the seat of the cycle and the City of the Cycle... ». (Edmonson 1982, p. 173)

\section{Transcriptions}

C u cutal ox lahun ahau katun ti lah bil cauac kin chil coba u hetz' katun ti ox lahun ahau may cu mayapan (T-Ed)

c-u-cu-tal oxlahun ahau katun ti lahb-il cauac kin chil coba u-hedz katun ti oxlahun ahau may cu mayapan $(\mathrm{T}-\mathrm{Br})$

cu cutal oxlahun ahau katun ti lahbil cauac kinchil coba u hedz katun ti oxlahun ahau may cu mayapan $(T-M i)$

lai bin u t'an kinchil coba $u$ hedz katun oxlahun ahau katun lae yetel may cu mayapan $(\mathrm{P}-\mathrm{Mi})$

\section{Morpheme Analysis}

c-u-cu-tal oxlahun ahau katun ti lahbil cauac kin chil coba u-hedz katun ti oxlahun ahau may cu mayapan

ADV-sit-DER.INC thirteen ahau katun PRE twelve cauac kin chil coba 3sERG-seat katun PRE thirteen ahau may cu mayapan

\section{Translations ${ }^{9}$}

«It sits, [the] 13 Ahau Katun on 12 Cauac Kinchil Coba is the seat of the katun in 13 Ahau [with] may cu Mayapan ».

"Then is seated the katun 13 ahau on 12 cauac Kin Chil of Coba seated the katun which was 13 ahau. The cycle seat was Mayapan... ». (Edmonson 1982, p. 182) 
I have presented the previous clauses before the sentence containing may $\mathrm{cu}$ to indicate the discourse structure and especially the use of the demonstrative (deictic) structure lay/lai... la-e as enframer which helps in a correct translation (see Smailus 1989, pp. 107-109):

Lai $u$ than $y$ an ychil $u$ cuch lae $y$ etel $u$ bel $y$ an ychil $u$ cuch hab i loe saciapan u hetz' katun ti cabil ahau sacl ac tun amay cu Mayapan

this is its word [which] is in its burden here and this is its road [which] is in the burden of this year here Saci(apan) is the seat of the katun in 2 Ahau [with] Saclactun amay cu Mayapan C u cutal ox lahun ahau katun ti lah bil cauac kin chil coba u hetz' katun ti ox lahun ahau may cu mayapan It sits, (the) 13 Ahau Katun on 12 Cauac

Kinchil Coba is the seat of the katun in 13 Ahau [with] may cu Mayapan

The Perez Codex example is a bit different but still conforms to the pattern and also helps to interpret the relationship among Saciapan and may cu Mayapan and Kinchil Coba and may cu Mayapan because of the mention of yetel in our last example:

lay u t'an yan ichil u cuch lae

yetel tulacal $u$ bel

bin t'anic u t'an

saciyapan $u$ hedz katun cabil ahau saclactun may cu mayapan

this is its word which is in its burden here

with all his/its roads

it will speak its words

Saciapan is the seat of the katun [of] Katun 2 Ahau [with] may cu Mayapan

lai bin u t'an

kinchil coba u hedz katun oxlahun ahau katun lae

yetel may cu mayapan

this, it is said, is its word

Kinchil Coba is the seat of the katun of this Katun 13 Ahau

with may cu Mayapan

These texts indicate that may $c u$ Mayapan is a toponym as they become the seat of the same katun with various other towns, once with Saciapan and then with Kinchil Coba. What is important here is to emphasise that yetel usually connects within a sentence entities which are semantically pertaining to the same category, in this case toponym and toponym. This may help to suggest another interpretation for the may cu sequence. On the other hand, there is no evidence for a translation of may $\mathrm{cu}$ as cycle seat.

May cu as maya cuzamil? 
As I have presented in my translations, Tizimin Lines 4879 and 5067 are descriptions of the end of several katun periods and their katun seats. In each case - as is attested elsewhere in Colonial Yukatek sources - several towns became the seats of a given katun and the sentences indicate that their toponyms are used in a specific embedded temporal and locative clause.

In each text segment, the actual utterance begins with the description of the burden within a specific katun which will be carried and uttered in different places. When the katun seat is named, there is always the additional information that this will occur in a specific numbered katun (in our cases 4 and 13 Ahau) and also where the actual settlement is situated. In this respect, these sentences are no different from line 2942 (my example 3) where Uxmal as the residence of Hun Uitzil Chac is situated on the landscape by an additional clause tu luumil tzucubte tu cuchcabal Mayapan may cu.

For a better understanding of these passages it is important to mention parallel katun seatings recorded in the Chilam Balam of Chumayel (pp. 72-74). On these pages there is a drawing of a katun-wheel with information written above each ahau head with the following syntactic structures (altogether there are 13 entries for a katun-wheel):
a, 8 examples-ti TOPONYM $u$ hetz' katun ti NUMBER ahau
b, 3 examples-TOPONYM $u$ hetz' katun ti NUMBER ahau
c, 1-1 example of the same structure with minor variations- $t i$ NUMBER ahau followed $t u$ TOPONYM/TOPONYM

From this sequence it is possible to reconstruct a full sentence which began with the place where the katun seating happened (ti TOPONYM), followed by the information about which katun the seating happened in (ti NUMBER ahau). This is parallel to the structure of the Tizimin passages which are in turn the same as the four longer katun seatings and prophecies on page 73 . It is crucial to understand these passages because they may inform us about may $\mathrm{cu}$.

In the Chumayel katun-wheel there is a short text corresponding to 2 Katun Ahau with a variation of the above reconstructed syntactic structure:

ti cabil ahau maya cu

çamil: maya pan

On the following page for the same 2 Katun Ahau we find a slightly different passage not dissimilar from the reconstructed sequence:

May lu'a ci maya patan u he [Katun: ti cabil Ahau katun

This is very similar to the information given in Tizimin and the Perez manuscripts just analysed above: 
saciapan u hetz' katun ti cabil ahau sacl ac tun amay cu Mayapan saciyapan u hedz katun cabil ahau saclactun may cu mayapan

Out of these four passages we can suggest that there were various toponyms where the katun was seated and they formed a list. While the Chumayel version is in two parts it is syntactically similar to the above Tizimin and Perez manuscripts sentences as the katun-wheel example repeats the toponymic information just as in the case of 4 Ahau where Uucyabnal as the seat of the katun has the added toponymic information tu Chic'een Itza:
may lu saci mayapatan uhetz'katun ti cabil ahau katun ti cabil ahau maya cusamil mayapan
saciapan uhetz'katun ti cabil ahau saclactun amaycumayapan saciyapan uhetz'katun cabil ahau saclactun may cu mayapan

From these parallel passages I would like to propose that the original suggestion of Roys (1949, p. 173, note 149; p. 177, note 228) must be accepted as the most plausible translation for may $\mathrm{cu}$ as an abbreviation of maya cuzamil, a toponym referring to the island of Cozumel to the east coast of the Yucatan peninsula.

While it is true that this toponym frequently precedes or follows the name of Mayapan, however it does not refer to it. Rather it is more similar to Saclactun which barely stands alone but it behaves as an independent place name in certain occasions (Chumayel p. 18 ca paxi cah Zaclahtun, p. 72 ti Zaclahtun).

Other indications that Maya Cuzamil Mayapan stood together come from two passages from the Chilam Balam of Yucatan where we have the following sentences:

p. 99C

cabil ahau katun u lahcatz'it katun maya uas cuzamil u hetz' katun

or « 2 Ahau Katun is the 12th katun. [Maya uas Cuzamil is the seat of the katun...] »

p. $100 \mathrm{C}$

tu yukul lay mehen cahob lae

tu yukul ca petenil Maya Cuzamil Mayapatan

or « ...in every small town here, everywhere in our land Maya Cuzamil Mayapatan... »

These Colonial Yukatek Maya examples strongly indicate that may cu should not be translated in these texts as cycle seat but as an abbreviation of Maya Cuzamil or a place name referring to Cozumel Island off the east coast of the Yucatan peninsula. From the various contexts, this particular combination of toponyms may refer, as a literary formula, to the Yukatan peninsula, or the former territories of Mayapan naming the centre and the easternmost boundary of this realm ${ }^{10}$. 


\section{Conclusions}

The translation of Classic and Colonial Maya texts has its caveats. In the case of the first one, there is the problem of decipherment and also that the recorded language is not spoken anymore and there were no bi-scripts or European priests and scholars who wrote dictionaries and grammars. In the case of the latter, it is indeed the recording with European letters and its general tendency of lacking punctuations (or diacritical marks) which make it more difficult to segment texts into morphologically valid components.

Also, the various copyists made their own errors and reinterpretations of text segments which already they did not understand correctly. The reading of parallel versions of the Chilam Balam manuscripts was a practice from their discoveries and was carried along by Brinton (1882), Barrera Vázques and Rendón (1948), Roys (1967) and Rivera Dorado (1986) who all tried to segment the texts into morphologically meaningful segments as was suggested by Hanks (1988) and later by Bricker and Miram (2002).

In certain cases, the parallel reading of texts can lead to a better understanding of the copying process and there were various proposals about the production of the manuscripts, most recently by Gunsenheimer (2002).

In this paper I analysed the occurrences of the root may in Classic Maya inscriptions and Colonial period Yukatek documents. I maintain that during the Classic period MAY and ma-ya could have referred to " powder and tobacco » and its derivations to a verb with the meaning of « to gift » (u-MAY-ji, MAY-ji) and there is no evidence whatsoever of the existence of a meaning of cycle or a hypothetical 256-year old period. This in turn concurs with the data from the Postclassic period when all these meanings of may are attested in addition to Kakchiquel may referring to a period of 20 years and arguably this was a loan word from Mixe-Soke languages.

On the Colonial Yukatek manuscripts I argued for the acceptance of the original suggestion of Roys that the term may $c u$ is an abbreviation for the toponymic maya cuzamil. Clearly, for the Postclassic and Colonial Yukatek the 13 times 20-year (or 24) period was an important cycle, nevertheless they never named that may. Rather, they used the terms $u$ tzolan/u xocan katunob or the ordering/counting of the katuns.

It is also true that katun-seatings or the stone planting was a tradition going back to the Classic or even Preclassic periods, however the Colonial Yukatek sources recorded that these katun-seating could have happened in various towns at the same time (as during the Classic period).

The famous description of Avendaño y Loyola (1987, p. 39) about the division of the katun wheel into thirteen parts is corroborated by the Chilam Balam manuscripts and it is plausible to suggest that this expressed an ideal picture, a 
sacred geopolitics as attested elsewhere in Mesoamerica and in the world. Partitions do not mean a unified rule. Classic period regional terms abound and all include numbers in their respective names such as Huk Tz'uk, Huxlaju'n Tz'uk, Huxlaju'n Kab', Huxte' Tuun, Huxte' Haab' and Kan Pet, etc. During the Classic period most of the sites which had inscriptions celebrated the seating of the katuns and various other smaller periods just as happened in the Postclassic; nevertheless this does not mean that there existed a cycle called may and competition to become a cycle seat. Evidence is sorely lacking for that in the Classic and the Postclassic period and I propose that any suggestion based on a may model should be dealt with scepticism. *

* Manuscrit reçu en octobre 2010, accepté pour publication en mai 2012.

\section{Notes}

Acknowledgments: I would like to thank Albert Davletshin, Antje Gunsenheimer, Barbara MacLeod and Guido Krempel for their comments and generous help with the manuscript. I thank Doorshysingh Jugessur for reading and correcting the manuscript. The writing of this paper was undertaken in the Abteilung für Altamerikanistik at the University of Bonn, Germany where I enjoyed a Postdoctoral Research period made possible by the Alexander von Humboldt Foundation.

1. I use Classic Ch'olan for one of the languages of Classic and Postclassic period Mayan inscriptions and manuscripts following Wichmann (2006). I accept that this language was the main language of the inscriptions and also played a prestigious role during the Classic and Postclassic Periods (Houston, Robertson and Stuart 2000).

2. I use Colonial Yukatek as the language recorded in Latin script documents from the middle of the 16 th century onward. Classical Yukatek is the language used in Classic period inscriptions from the 8 th to the 10th centuries in the northern part of the Yucatan peninsula. It is still under debate what is the status of Yukatek words and grammatical structures recorded in the three existent codices. Clearly there is a 550-year gap between the last attestation of Yukatek in Classic period inscriptions and the first Latin script Colonial Yukatek texts.

3. The decipherement of [T25-528-25] as WINAK/WINIK was suggested by various epigraphers independently (among them David Stuart and Yuriy Polyukhovich; personal communication with Albert Davletshin, 27 January, 2010). The first article I know of which mentions that decipherment is by Stuart (1996, p. 155).

4. The derived noun tajal comes from taj- which, in Colonial Yukatek, meant « owner, possessor of something ", hence the translation of tajal as possession (Wagner 1995, p. 110). However, recently Albert Davletshin suggested to the author that this interpretation has various linguistic problems and he proposed that the root of this expression is the Colonial Yukatek taah « farsa, representación » and tajal thus would be « representative », which fits the context well (here and elsewhere in the inscriptions of Chichen Itza).

5. Epigraphers usually transcribe this verb as cha'n taking into account that the -nu phonetic complement indicates a glottal stop. Lacadena and Wichmann (2004, p. 140) argue that this word relates to cognates of the Chol cha'an «master, owner» and for them the late spellings CHAN-na would attest to a stage where the glottal stop was already lost from the language of the inscriptions. However, this would not fit the Chol data where the glottal is present as they pointed out. One seemingly abberant spelling CHAN-na-ni/chanaan from Quirigua may point to another solution, namely that this is a participle derived from the attested verb to guard, to watch over. In this case CHAN-nu would be chana'n and the whole sequence of $u$ chana'n NAME1 NAME2 can be translated 
as « his guarded thing is NAME1 » and NAME2 would begin an independent new stative phrase as « he is NAME2 ».

6. «I have chosen to translate the Tizimin blind, without prior consultation of the previous attempts or prior knowledge of the detailed parallel Spanish history of Yucatan. My endeavor was to gain an unbiased and presumably Mayan - or at least endogenous - view of the work. I believe I have done that » (Edmonson 1982, pp. xiv-xv).

7. For the transcriptions, I use the following abbreviations: T-Ed = Tizimin Edmonson, $\mathrm{T}-\mathrm{Br}=$ Tizimin Bricker, $\mathrm{T}-\mathrm{Mi}=$ Tizimin Miram, $\mathrm{P}-\mathrm{Mi}=$ Perez Miram.

8. Abbreviations are ADV (adverb), DEI (deictic), DEM (demonstrative), ERG (ergative pronoun), PAR.COMP (completive participle), PAR.EXP (expectative participle), PRE (preposition), POSS.PAR (possessive particle), PRO.FOC (focal pronoun), SUBJ (subjunctive particle).

9. The transcription and translations are mine.

10. Gunsenheimer (2002, p. 371) interpreted the expressions ich paa mayapan and tan cah mayapan in various passages of the Chilam Balam as references to two separate sites which the compilators of the manuscripts merged together into a single entity. She suggested to me that Maya Cuzamil Mayapan may have been similar to the above expressions (e-mail dated to 04/08/2010). Generaly the above two expressions are translated as " within the wall of Mayapan » and " in the settlement of Mayapan ", respectively.

\section{REFERENCES CITED}

ALMG

2001 Q'orik Pokomchi'-vocabulario Pokomchi', Dirección Lingüística y Cultural ALMG, Academia de Lenguas Mayas de Guatemala, Guatemala.

Avendaño y Loyola Fray Andrés de

1987 Relation of two trips to Peten. Made for the conversion of the heathen Ytzaex and Cehaches, Labyrinthos, Culver City.

BARRERA VÁSQUEZ Alfredo

1980 Diccionario Maya Cordemex, Ediciones Cordemex, Mérida.

BARRERA VÁSQUEZ Alfredo and Silvia RENDóN

1948 El Libro de los libros de Chilam Balam, Fondo de Cultura Económica, Mexico.

Beltrán de Santa Rosa Maria fray Pedro

2001 Arte de el idioma maya, reducido a succintas reglas, y semilexicón Yucateco, Yucatán, México, por la viuda de D. Joseph Benardo de Hogal [1746] [http://www.famsi.org/reports/96072/beltrangmr.htm].

BRETON Alain

2004 Rabinal Achi. Un drame dynastique maya du quinzième siècle, Édition établie d'après le manuscrit Pérez, Société des Américanistes/Société d'Ethnologie, Nanterre.

BRICKER Victoria

1990a A morpheme concordance of the book of Chilam Balam of Tizimin, Tulane University, coll. « Middle American Research Institute » 58, New Orleans. 1990b Amorpheme concordence of the book of Chilam Balam of Chumayel, Tulane University, coll. « Middle American Research Institute » 59, New Orleans. 
BRICKer Victoria and Helga-Maria Miram

2002 The Encounter of two worlds: the book of Chilam Balam of Kaua, Tulane University, coll. « Middle American Research Institute » 68, New Orleans.

BRINTON Daniel G.

1882 The Maya chronicles, Brinton's Library of Aboriginal American Literature, 1, Published by the Author, Philadelphia.

BUONAVENTURA Gabriel

1996 Arte de la lengua maya, edición de René Acuna, Instituto de Investigaciones Filológicas, Centro de Estudios Mayas/Universidad Nacional Autónoma de México, coll. « Fuentes para el estudio de la cultura maya »13, Mexico [1684].

EDMONSON Munro S.

1965 Quiché-English dictionary, Tulane University Press, coll. » Middle American Research Institution Publication » 30, New Orleans.

1979 «Some Postclassic questions about the Classic Maya », in Merle Greene Robertson and Donnan Call Jeffers (eds), Third Palenque Round Table. Vol. 4. Palenque, Chiapas, Mexico, Pre-Columbian Art Research Center, San Francisco, pp. 9-18.

1982 Ancient future of the Itzá: the book of Chilam Balam of Tizimin, University of Texas Press, Austin.

1986 The heaven born Merida and its destiny: the book of Chilam Balam of Chumayel, University of Texas Press, Austin.

García CAmpillo José Miguel

2000 Estudio introductorio del léxico de las inscripciones de Chichén Itzá, Yucatán, México, Archaeopress, coll. «BAR International Series » 831, Oxford.

GorDON George B.

1913 The Book of Chilam Balam of Chumayel, University Museum of Pennsylvania, Philadelphia.

GunSENHEIMER Antje

2002 Geschichtsradinrung in den yukatekischen Chilam Balam-Büchern: eine Analyse der Herkunft und Entwicklung ausgewählter historischer Berichte, Inaugural-Dissertation zur Erlangung der Doktorwürde der Philosophischen, Fakultät der Rheinischen Friedrich-Wilhelms-Universität zu Bonn. « En contra del olvido y en pro de la continuidad: las crónicas de los Libros del Chilam Balam en su contexto colonial », in Hanns J. Prem (ed.) Escondido en la selva: arqueología en el norte de Yucatan, Instituto Nacional de Antropologia e Historia/Universidad de Bonn, Mexico, pp. 371-416.

2006 " Out of the historical darkness: a methodological approach to uncover the hidden history of ethnohistorical sources », Indiana, 23, pp. 15-50.

Gunsenheimer Antje, Tsubasa Okoshi Harada and John F. Chuchiak (eds)

2009 Text and context: Yucatec Maya literature in a diachronic perspective $=$ texto y contexto: la literatura maya yucateca en perspectiva diacrónica, Bonner Amerikanistische Studien, Bonn. 
HANKs William

1986 «Authenticity and ambivalence in the text: a colonial Maya case », American Ethnologist, 13, pp. 721-744.

1987 «Discourse genres in a theory of practice », American Ethnologist, 14, pp. 64-88.

1988 "Grammar, style, and meaning in a Maya manuscript », International Journal of American Linguistics, 54 (3), pp. 331-369.

1989 «Elements of Maya style », in William F. Hanks and Don S. Rice (eds), Word and image in Maya culture: explorations in language, writing, and representation, University of Utah Press, Salt Lake City, pp. 92-111.

$2010 \quad$ Converting words: Mayan in the age of the cross, University of California Press, Berkeley.

Hull Kerry

2003 Verbal art and performance in Ch'orti' and Maya hieroglyphic writing, $\mathrm{Ph} \mathrm{D}$. dissertation, Department of Anthropology, University of Texas, Austin.

Houston Stephen D., John Robertson and David Stuart

2000 "The language of Classic Maya inscriptions », Current Anthropology, 41 (3), pp. 321-356.

JUSTESON John and Lyle CAMPELL

1997 «The linguistic background of Maya hierogplyphic writing: arguments about a "Highland Mayan" role ", in Martha J. Macri and Anabel Ford (eds), The language of Maya hieroglyphs, Pre-Columbian Art Research Institute, San Francisco, pp. 41-67.

KNOWLTON Timothy

$2010 \quad$ Maya creation myths: words and worlds of the Chilam Balam, University of Colorado Press, Boulder.

LaCADENa Alfonso and Søren WichmanN

2004 "On the representation of the glottal stop in Maya writing », in Søren Wichmann (ed.), The linguistics of Maya writing, University of Utah Press, Salt Lake City, pp. 100-164.

Maxwell Judith M. and Robert M. HiLl

2006 Kakchiquel chronicles. The definitive edition, University of Texas Press, Austin.

McQuown Norman

1967 «Classical Yucatec (Maya)», in Robert Wauchope (ed.), Handbook of Middle American Indians. Vol. 5. Linguistics, University of Texas Press, Austin, pp. 201-247.

MiLES Suzanne W.

1957 «The Sixteenth-Century Pokom Maya: a documentary analysis of social structure and archaeological settings », Transactions of the American Philosophical Society, 57 (4), pp. 733-781, Philadelphia.

Miram Helga-Maria and Wolfgang Miram

1988a Konkordanz der Chilam Balames, 6 vols, Toto Verlag, Hamburg.

1988b Transkriptions der Chilam Balames, 4 vols, Toto Verlag, Hamburg. 
Pollock Sheldon

2009 «Future philology? The fate of a soft science in a hard world », Critical Inquiry, 35, pp. 931-961.

Restal Matthew

1998 Maya conquistador, Beacon Press, Boston.

2003 «A history of the new philology and the new philology in history », Latin American Research Review, 38 (1), pp. 113-134.

RICE Prudence

2004 Maya political science: time, astronomy and the cosmos, University of Texas Press, Austin.

2007 Maya calendar origins, University of Texas Press, Austin.

2008 «Time, power, and the Maya", Latin American Antiquity, 19 (3), pp. 275-298.

Rivera Dorado Miguel

1986 Chilam Balam de Chumayel, Dastin Historia, coll. «Crónicas de America » 20/coll. « Historia »16, Madrid.

Robertson John S., Danny Law and Robbie A. HaErTel

$2010 \quad$ Colonial Ch'olti': The Seventeenth-Century Moran manuscript, University of Oklahoma Press, Norman.

Roys Ralph R.

1949 «Prophecies for the Maya tuns or years in the books of Chilam Balam of Tizimin and Mani », Carnegie Institution of Washington, Contributions to American Anthropology and History, 10 (51), pp. 153-186.

1967 The Book of Chilam Balam of Chumayel, University of Oklahoma Press, Norman.

SMAILUS Ortwin

1989 Gramática del maya yucateco colonial, Wayasbah, Hamburg.

STUART David

1996 « Kings of stone: a consideration of stelae in Ancient Maya ritual and representation », RES. Anthropology and Aesthetics, 29-30, pp. 148-171.

2005 The inscriptions at temple XIX at Palenque: a commentary, Pre-Columbian Art Research Institute, San Francisco.

TEDLOCK Denis

1983 The spoken word and the work of interpretation, University of Pennsylvania Press, Philadelphia.

20102000 years of Mayan literature, University of California Press, Berkeley.

van AKKeren Ruud

$2000 \quad$ Place of the Lord's daughter. Rabinal, its history, its dance-drama, Research School CNWS, Leiden.

Voss Alexander W. and H. Juergen KremER

2000 "K'ak'-u-pakal, Hun-pik-tok' and the Kokom: the political organization of Chichen Itzá », in Pierre Robert Colas, Kai Delvendahl, Marcus 
Kuhnert and Annette Schubart (eds), The sacred and the profane: architecture and identity in the Maya Lowlands, 3rd European Maya Conference, University of Hamburg, November 1998, Acta Mesoamericana 10, Verlag Anton Saurwein, Markt Schwaben, pp. 149-181.

WAGNER Elisabeth

1995 Personennamen und relationale Glyphen in den Inschriften von Chichen Itza, Yucatan, Mexico, MA Thesis, Fachbereich Altertumwissenschaften, Freien Universität Berlin, Berlin [unpublished].

WichmanN Søren

2006 "Mayan historical linguistics and epigraphy: a new synthesis », Annual Review of Anthropology, 35, pp. 279-294. 